7 Steinmann-Zwicky, M. (1988) EMBO J. 7, 3889-3898

8 Oliver, B., Perrimon, N. and Mahowald, A.P. (1988) Genetics 120, 159-171

9 Cline, T.W. (1984) Genetics 107, 231-277

10 Lucchesi, J.C. and Manning, J.E. (1987) Adv. Genet. 24 $371-429$

11 Brown, E.H. and King, R.C. (1961) Genetics 46, 143-156

12 Seidel. S. (1963) Z. Vererbungsl. 94, 215-241

13 Nöthiger, R. et al. (1989) Development 107, 505-518

14 Marsh, J.L. and Wieschaus, E. (1978) Nature 272, 249-251

15 Schüpbach, T. (1982) Det'. Biol. 89, 117-127

16 Schüpbach, T. (1985) Genetics 109, 529-548

17 Steinmann-Zwicky, M., Schmid, H. and Nöthiger, R. (1989) Cell 57, 157-166

18 Hildreth, P.E. (1965) Genetics 51, 659-678

19 Nöthiger, R., Roost, M. and Schüpbach, T. (1980) Drosophila Inf. Serv. 55, 118

20 Brown, E.H. and King, R.C. (1962) Growth 26, 53-69

21 Gehring, W.J., Wieschaus, E. and Holliger, M. (1976) J. Embryol. Exp. Morphol. 35, 607-616

22 Szabad, J. and Fajszi, C. (1982) Genetics 100, 61-78

23 Van Deusen, E.B. (1976) J. Embryol. Exp. Morphol. 37, 173-185

24 Bachiller, D. and Sanchez, L. (1986) Dev. Biol. 118, 379-384

25 Busson, D., Gans, M., Komitopoulou, K. and Masson, M. (1983) Genetics 105, 309-325

26 Perrimon, N. (1984) Genetics 108, 927-939

27 Oliver, B., Perrimon, N. and Mahowald, A.P. (1987) Genes Dev. 1. 913-923

$\mathrm{U}_{\mathrm{n}}$ til recently, it was thought that gene expression did not occur in animal gametes. Post-meiotic gene expression appeared to run counter to the evolutionary dogma that genetic selection should only be zygotic gene expression in gametes could result in phenotypic differences affecting function and could potentially be subject to selection. Such post-meiotic expression was found over half a century ago in plants, where one male pronucleus is activated during pollen formation. While the occurrence of distorted transmission ratios related to selection for different alleles was described then in plants 1 , a direct demonstration of new RNA synthesis in the pollen tube, the description of pollen tube-specific isozymes, and the recording of the frequency of post-meiotic gene expression are more recent (reviewed in Ref. 2)

At the same time that the first evidence for postmeiotic gene expression in plants was being obtained, quite an opposite conclusion about gene expression in animal gametes was reached by Muller ${ }^{3}$. He found that sperm nullisomic for about $1 / 40$ of the Drosopbila genome, due to an unbalanced translocation, could fertilize aggs normally if the missing material was contributed to the zygote by eggs disomic for the missing material. The results were extended to most of the Drosophila genome and similar conclusions were derived from similar experiments in mice ${ }^{4}$, but in both cases the authors were unaware of the syncytial nature of spermatogenesis. In mammals, large $(1 \mu \mathrm{m})$ intercellular bridges can connect over a hundred spermatids, while in Drosophila 64 spermatids develop
28 Mével-Ninio, M., Mariol, M-C. and Gans, M. (1989) EMBO J. 8, 1549-1558

29 Oliver, B., Pauli, D. and Mahowald, A.P. Genetics (in press)

30 Gollin, S.M. and King, R.C. (1981) Dev. Genet. 2, 203-218

31 Salz, H.K., Cline, T.W. and Schedl, P. (1987) Genetics 117, 221-231

32 Bell, L.R., Maine, E.M.. Schedl, P. and Cline, T.W. (1988) Cell 55, 1037-1046

33 Salz, H.K. et al. (1989) Genes Dev. 3, 708-719

34 King, R.C. et al. (1986) Dev. Genet. 7, 1-20

35 Storto, P.D. and King, R.C. (1988) Dev. Genet. 9, 91-120

36 Steinhauer, W.R., Walsh, R.C. and Kalfayan, L.J. (1989) Mol. Cell. Biol. 9, 5726-5732

37 King, R.C. (1970) Ovarian Develcpment in Drosophila melanogaster, Academic Press

38 Mori, L. and Perondini, A.L.P. (1980) Genetics 94, 663-673

39 Ullerich, F-H. (1984) Mol. Gen. Genet. 193, 479-487

40 Inoue, H. and Hiroyoshi, T. (1986) Genetics 112, 469-481

41 McLaren, A. (1988) Trends Genet. 4, 153-157

42 Goodfellow, P.N. and Darling, S.M. (1988) Development $102,251-258$

D. PaUt and A.P. Mahowald are in the Department of Genetics, SChOOL OF Medicine, Case Western Reserve UNIVERstTy, CleVtelang, OH 44106, USA; PRESENT ADdRESS fOR A.P.M.: DePaRtMeNT OF MOLECULAR GeNeTICS AND CELL BIOLOGY, UNIVERSITY OF CHICAGO, CHICAGa, IL 60637, USA.

\section{Post-meiotic gene expression}

\section{ROBERT P. ERICKSON}

\section{Evolutionary arguments and well-designed experiments (based on false premises, bowever) bad suggested that post-meiotic gene expression did not occur in animals. The tecbniques of molecular genetics bave now clearly demonstrated sucb genetic activity in mammalian testes. The current problem is to understand wby some classes of genes, sucb as Zfy and many oncogenes, are expressed in this manner.}

without interposed cell membranes. Such cytoplasmic continuity could allow the products of any genes that might be expressed post-meiotically to be shared among haploid nucleis. While the sharing of ? postmeiotically expressed gene product in spermatiois of a heterozygous transgenic mouse has now been shown ${ }^{6}$, it has not yet been shown in Drosophila, but a clearcut case of post-meiotic transcription involves a nuclearretained heat shock gene transcript (W.G. Bendena, A. Ayme-Southgate, J.C. Garbe and M.L. Pardue, unpublished). In contrast to the infrequent detection of post-meiotic transcription in Drosophila 7 , a plethora of such transcription has now been found in mammals so much so that one wonders why it should be so common. This review will examine the development 


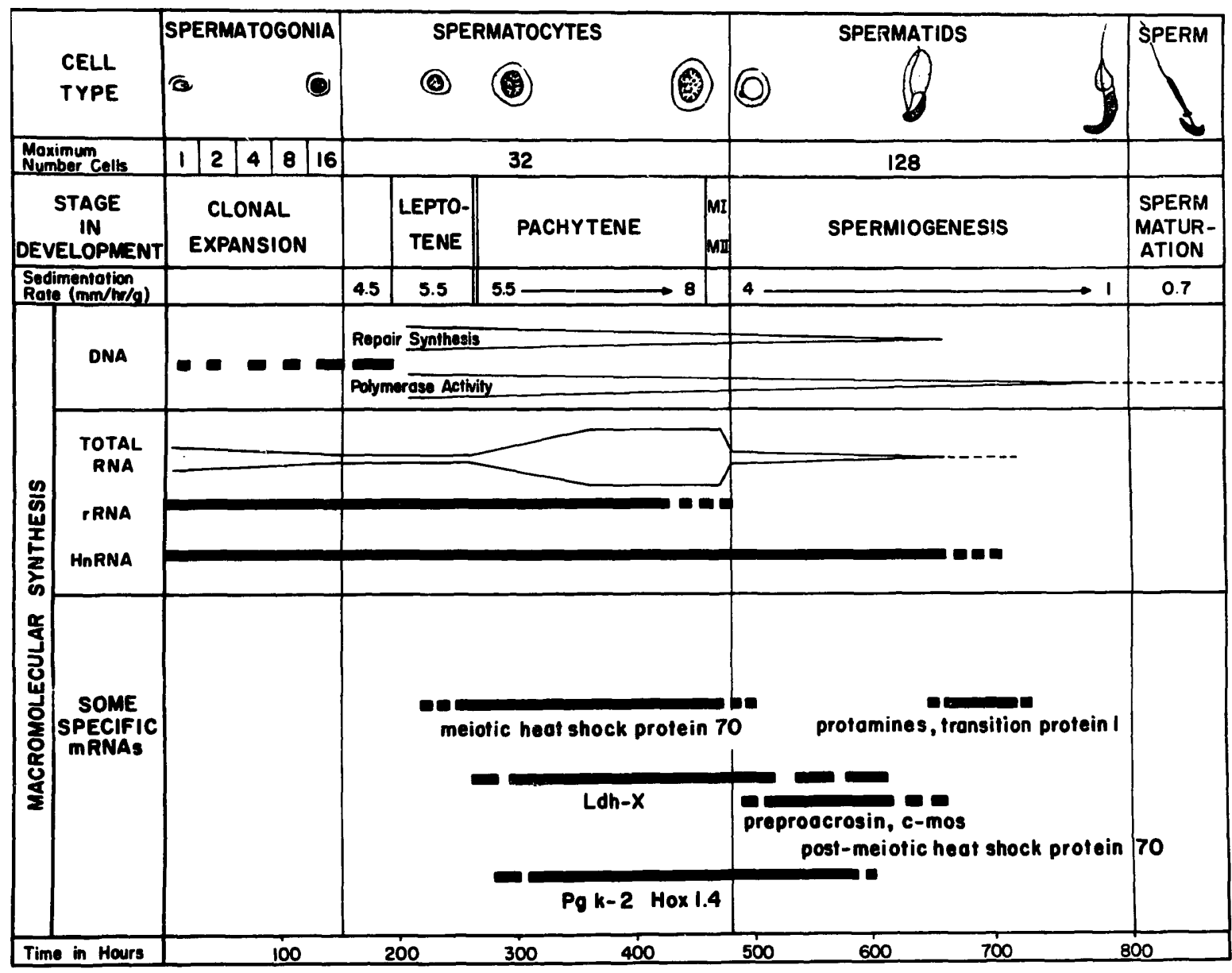

FIG 1

A schematic representation of spermatogenesis. Qualitative data for macromolecular synthesis are indicated by solid bars; uncertainties about onset or duration are indicated by breaks. Quantitative variations for a single substance are indicated by the relative heights of the margined areas; no comparison from one substance to another is intended. Modified from Ref. 39 and reproduced with permission of Elsevier Scientific Publications.

of this new view and discuss the question of the possible functions of post-meiotic gene expression.

\section{Evidence for post-meiotic gene expression}

The time interval between the meiotic divisions of oogenesis and fertilization is so short (sometimes the meiotic divisions are triggered by fertilization) that there is little or no time for post-meiotic, gamete-limited gene expression during egg development. Thus, we are concerned with pcst-meiotic gene expression during spermatogenesis. The overall features of spermatogenesis were recently reviewed by Willison and Ashworth in $T 7 G^{8}$ and are summarized in Fig. 1. Spermatogenesis refers to all the steps from spermatogonia to mature sperm, while spermiogenesis refers to the phase of marked morphological differentiation that starts with the post-meiotic spermatid. It was originally believed that little RNA was transcribed after meiosis, since early mouse spermatids exposed to short pulses of $[3 \mathrm{H}]$ uridine showed only a very small peak of incorporation when examined by autoradiography. However, more recent quantitstive autoradiographic studies have demonstrated that the rate of RNA synthesis per cell decreased fourfold during meiosis, so the RNA synthesis/DNA ratio was unchanged?. Studies on separated testicular cells confirmed that there are high rates of RNA synthesis in post-meiotic cell stages. Direct visualization of transcription by electron microscopy indicates that both ribosomal and heterogeneous nuclear RNA are synthesized in spermatocytes, but nucleolus-like ribosomal RNA transcription patterns were not found after meiosis ${ }^{10}$. Thus, the new RNA synthesis after meiosis is not merely ribosomal RNA. Sucrose gradient and electrophoretic characterization of newly synthesized RNA from spermatids demonstrated heterogeneous presumptive $\mathrm{mRNA}^{11}$.

As more tools of molecular biology were developed and applied to the characterization of postmeiotically synthesized RNA, the results were surprising: Analysis by two-dimensional gel electrophoresis of the products of in vitro translation of RNA purified from separated spermatocytes and spermatids showed twice as many spermatid-specific as spermatocyte-specific gene products, with only a relatively small number of proteins synthesized in both cell types (Fig. 2). Assays for the mRNA for specific proteins (by in vitro translation from purified RNA) demonstrated that mRNA for protamine and 
phosphoglycerate kinase-2 (PGK-2) increased after meiosis ${ }^{12}$. However, since the mRNAs might have been transcribed earlier, and only processed postmeiotically, these results did not yet prove that there was post-meiotic transcription. Thereafter, several groups made cDNA libraries and found clones for specific mRNAs that increased, or first appeared, after meiosis ${ }^{13-15}$. A survey of testicular cDNAs showed that about half increased in abundance after meiosis ${ }^{16}$ About half of these (a quarter of the total) first appeared after meiosis ${ }^{16}$. Thus, ample confirmation of post-meiotic gene expression has been obtained.

\section{Classes of post-meiotically transcribed genes}

Of the many genes now known to be transcribed post-meiotically, this pattern of transcription makes sense for some but not others (Tables 1 and 2). It is easily understood for sperm-specific proteins whose transcription occurs near the time of translation - the usual scenario in development. For example, the mRNA for sperm-specific $\alpha$-tubulin, perhaps needed for cytoskeletal reorganization during the dramatic structural changes that occur during spermiogenesis, or for the sperm flagellum itself, does not even appear until the late spermatid stage ${ }^{17}$. This may also be the reason for post-meiotic transcription of $\gamma$-actin, which has been identified as the product of the gene that also codes for the $\gamma$-actin in sriouth muscle ${ }^{18}$

The mRNAs for LDH-X (a lactate dehydrogenase isozyme) and PGK-2, two sperm-specific isozymes, both appear earlier but increase in abundance after meiosis. In the case of LDH-X, almost half the synthesis occurs before the first meiotic metaphase, but nuclear run-off experiments demonstrate continued post-meiotic transcription ${ }^{15}$. In the case of PGK-2, there is transcription at pachytene with further transcription occurring after meiosis ${ }^{19}$, but little or none of the pre-meiotically transcribed message is found on polysomes, while the specific mRNA is abundantly found on polysomes after meiosis. The expression of $P g k-2$ is thought to compensate for the extinction of expression of X-linked Pgk-1 due to post-meiotic Xinactivation. It has been proposed that the abundant expression of LDH-X reflects a need for its altered substrate specificity in spermatozoa. However, its expression might be related to its ability to bind singlestranded DNA, which could play a role in chromatin reorganization.

Protamine, transition protein 1 , and testicular histone $2 \mathrm{~B}$ are chromatin proteins clearly involved in the massive reorganization of DNA in the sperm nucleus. One would predict that they would not be needed until after meiosis and it has been repeatedly demonstrated that they are iranscribed after meiosis $13.20,21$. Post-meiotic transcription of histone $2 \mathrm{~B}$ has also been confirmed by nuclear run-off experiments ${ }^{21}$. Preproacrosin is a precursor of a sperm enzyme involved in fertilization and the transcript does not appear until after meiosis22.

The reasons for the abundant post-meiotic expression of genes such as oncogener, homeobox genes, and even the putative sex-deterlining gene, zinc finger $\mathrm{Y}\left(Z_{f} f\right)$, are less clear (Tabls 1 and 2 ). Testicular cell protein 1 (TCP 1) was known to be expressed at low levels in other tissues. It has only recently become apparent that its great,y increased synthesis during spermiogenesis, which is included in the phase of post-meiotic transcription, is probably related to its role in Golgi complex function ${ }^{23}$, since the Golgi complex becomes greatly enlarged (and apparently more active) in preparation for acrosome formation. The expression of a unique postmeiotic heat shock protein ${ }^{24}$ could be related to the unique temperature sensitivity of mammalian spermatogenesis. One feature in common among $Z f y$, which is transcribed postmeiotically 25 , and some of the oncogenes and developmental genes, is the potential to encode DNA-binding proteins. Zfy contains the zinc finger motif found in transcription factor IIIA and other DNA-binding proteins; it is conceivable that $Z f y$, the ret finger protein (rfp) 26 and Hox 1.4 (Ref. 27) might be genes that play a role in nuclear DNA reorganization.

However, the post-meiotic transcription of other oncogenes (reviewed in Ref. 28) is surprising, given that the sperm is a terminally differentiated cell type, and bespeaks our lack of knowledge about the function of cellular oncogenes in normal development. The c-mos (Ref. 28), c-abl (Ref. 29) and
Diagram of protein patterns on two-dimensional gels from in vitro translation of purified RNA in spermatocytes versus spermatids based on multiple gels of each cell type. Spermatid-specific proteins are indicated by filled, numbered traces; spermatocyte-specific proteins by unfilled, unnumbered traces; and proteins common in both cell types by filled, unnumbered traces. Reproduced from Ref. 40 with permission of Academic Press. 
$R_{\text {EVIEWS }}$

c-pim-1 (Ref. 28) genes encode kinases (and part of $\mathrm{rfp}$ is also a kinase), while $\mathrm{c}-\mathrm{N}$-ras (Ref. 28) encodes a GTP-binding protein; such functions do not have an obvious role in spermiogenesis. Perhaps the identification of the c-mos gene product as the cyiostatic factor CSF, involved in cleavage arrest ${ }^{30}$, is relevant to its transcription post-meiotically when spermatids lose their potential to divide. The c-int-1 gene codes for a secreted protein, perhaps a growth factor, that is expressed in the embryonic nervous system (and its homologue in Drosopbila, wingless, has a role in early development) but it has no obvious role in spermiogenesis 31 .

We get little help in our understanding of the role of these oncogenes in post-meiotic germ cells by contrasting them with proto-oncogenes expressed pre-meiotically. High levels of c-myc and c-jun mRNAs are found in spermatocytes ${ }^{32}$. Both encode nuclear proteins and the c-jun gene product complexes with the c-fos product (expressed at high levels in spermatogonia32), to form a DNA-binding complex whose target sequence is the activator protein-1 (AP-1) binding site. The expression of trans-acting factors binding to the AP-1 site may be involved in the transcriptional control of genes that begin to be expressed at or near the time of meiosis. The role in spermiogenesis ${ }^{33}$ of preproenkephalin, an endogenous opioid precursor in the central nervous system, is also far from clear. Calmodulin $^{22}$ has many potential roles during
Tame 1. Some genes that have been shown to be transcribed post-meiotically

\begin{tabular}{|c|c|c|c|}
\hline Name & $\begin{array}{l}\text { Thine of first } \\
\text { appearance }\end{array}$ & $\begin{array}{l}\text { Nature of } \\
\text { evidence }\end{array}$ & Reference \\
\hline \multicolumn{4}{|l|}{ Sperm/testes specific } \\
\hline a-tubulin & Late spermatids & Northern ${ }^{2}$ & 17 \\
\hline Heat shock protein 70 & $\begin{array}{l}\text { Pachytene } \\
\text { spermatocytes }\end{array}$ & Northern & 24 \\
\hline LDH-X & $\begin{array}{l}\text { Pachytene } \\
\text { spermatocytes }\end{array}$ & Nuclear run-off & 15 \\
\hline$P g k-2$ & $\begin{array}{l}\text { Pachytene } \\
\text { spermatocytes }\end{array}$ & Northern & 19 \\
\hline Protamine & Round spermatids & Northem & 13 \\
\hline Preproacrosin & Spermatids & $\begin{array}{l}\text { In situ } \\
\text { hybridization }\end{array}$ & 22 \\
\hline $\begin{array}{l}\text { Transition protein } \\
\text { one }\end{array}$ & Spermatids & $\begin{array}{l}\text { In situ } \\
\text { hybridization }\end{array}$ & 20 \\
\hline \multicolumn{4}{|l|}{ Not germ-line specific } \\
\hline $\begin{array}{l}\text { Actin, smooth } \\
\text { muscle type }\end{array}$ & Late spermatids & Northern & 18 \\
\hline $\begin{array}{l}1 \mathrm{~kb} \text { calmodulin } \\
\text { c-int-1 oncogene }\end{array}$ & $\begin{array}{l}\text { Round spermatids } \\
\text { Spermatids }\end{array}$ & $\begin{array}{l}\text { Northern } \\
\text { Northern }\end{array}$ & $\begin{array}{l}22 \\
31\end{array}$ \\
\hline $\begin{array}{l}\text { Tcp-1 (testicular cell } \\
\text { protein-1) }\end{array}$ & Earliest stages & Northern & 21 \\
\hline Zinc finger $Y$ & Spermatids & Northern & 25 \\
\hline Male enhanced antigen & Earliest stages & Northern & 34 \\
\hline
\end{tabular}

aThe term 'northern' indicates that northern analyses have demonstrated increased amounts of specific RNA in separated post-meiotic cells.

The term 'in situ hybridization' indicates that specific RNA is found only in spermatids or is greatly increased in post-meiotic stages.

spermiogenesis, while the function of male enhanced antigen $^{34}$ is unknown. Clearly, inactivational or mutational analysis of the role of these gene products in spermatogenesis is needed.

TABux 2. Genes with altered splicing/processing during post-meiotic transcription

\begin{tabular}{|c|c|c|c|c|c|}
\hline $\begin{array}{l}\text { Class } \\
\text { of gene }\end{array}$ & Name & $\begin{array}{l}\text { 'Normal' } \\
\text { tisoue of } \\
\text { expression }\end{array}$ & $\begin{array}{l}\text { Characteristics } \\
\text { of normal } \\
\text { transcript }\end{array}$ & $\begin{array}{l}\text { Alterations in post- } \\
\text { meiotically expressed } \\
\text { transcript }\end{array}$ & References \\
\hline \multirow[t]{5}{*}{ Oncogenes } & $c-a b l$ & Many & 5.5 and $6.5 \mathrm{~kb}$ & $\begin{array}{l}4.0 \text { kb with truncated } 31 \\
\text { terminus, polyadenylation } \\
\text { at unusual site without } \\
\text { consensus polyadenylation } \\
\text { signal }\end{array}$ & 29 \\
\hline & $c-m o s$ & Many & $1.3,1.4$ and $2.3 \mathrm{~kb}$ & $1.7 \mathrm{~kb}$ & 28 \\
\hline & c-pim-1 & Immune tissues & $2.8 \mathrm{~kb}$ & $2.4 \mathrm{~kb}$ & 28 \\
\hline & $\begin{array}{l}\text { Ifp (ret finger } \\
\text { protein) }\end{array}$ & Many & $2.4 \mathrm{~kb}, 3.4 \mathrm{~kb}$ & $2.8 \mathrm{~kb}$ & 26 \\
\hline & $\mathrm{N}$-ras & Many & $1.3,2.4$ and $5.0 \mathrm{~kb}$ & $1.3 \mathrm{~kb}$ & 27 \\
\hline $\begin{array}{l}\text { Developmental } \\
\text { genes }\end{array}$ & Hax 1.4 & $\begin{array}{l}\text { Embryonic } \\
\text { spinal cord }\end{array}$ & $1.7,2.4 \mathrm{~kb}$ & $\begin{array}{l}1.35 \mathrm{~kb} \text { in spermatocytes, } \\
1.45 \mathrm{~kb} \text { in spermatids }\end{array}$ & 27 \\
\hline \multirow[t]{2}{*}{ Others } & Histone 2B & Testes & $\begin{array}{l}500 \text { bp not } \\
\text { polyadenylated }\end{array}$ & $\begin{array}{l}800 \text { bp polyadenylated plus } \\
12 \text { extra C-terminal amino acids }\end{array}$ & 21 \\
\hline & $\begin{array}{l}\text { Preproen- } \\
\text { kephalin }\end{array}$ & Brain & $1500 \mathrm{bp}$ & $\begin{array}{l}1900 \mathrm{bp} \text {, little metenkephalin } \\
\text { peptide detected }\end{array}$ & 33 \\
\hline
\end{tabular}


Altered post-meiotic transcripts and polyadenylation

As Table 2 shows, genes that are expressed both post-meiotically in round spermatids, and in other tissues, often produce different transcripts in these tissues. Some apparent examples of this have turned out to be due to transcription from different genes. For example, in the case of heat shock protein 70 there was cross-hybridization of the probe to the transcript of a different gene that was being uniquely expressed in testes ${ }^{24}$. In the case of histone 2B (Ref. 21), it is possible that the 500 bp testis transcript is from a testisspecific gene, but not the one that gives rise to the 800 bp polyadenylated transcript. However, in many other cases there is clear evidence for alternative splicing and/or processing from the same gene. For instance, c-abl has multiple transcripts in lymphoid tissues, resulting from differential splicing of $5^{\prime}$ exons. However, the short $4 \mathrm{~kb}$ mRNA that is found in testis results from premature termination, with polyadenylation at a site apparently lacking consensus polyadenylation signals 29 . Oppi et al. ${ }^{29}$ conclude that 'testis cells contain special enzymes that have different sequence specificity for transcription termination and polyadenylation compared with their somatic cell counterparts'.

It has been found for many post-meiotically transcribed genes, including protamines and transition proteins, that the initial mRNA has a long poly(A) tract which shortens as the messages shift from the nonpolysomal to the polysomal compartment 35 . In general, the presence of long polyadenylation tracts has been found for messages whose synthesis begins after meiosis, but which are not translated until later stages of spermiogenesis. On the other hand, in the case of LDH-X, for which transcription and translation start pre-meiotically with continued transcription after meiosis, the polyadenylation increases after meiosis ${ }^{36}$. Perhaps the changes in transcription termination or polyadenylation in post-meiotic cells might be related to changes in the poly(A)-binding protein, which determines mRNA stability in vitro and is required for $60 \mathrm{~S}$ ribosomal subunit-dependent translation initiation ${ }^{37}$.

While it has been demonstrated in transgenic mice that the $5^{\prime}$ regions of some post-meiotically expressed genes contain the sequence information required for correct timing of expression, only recently have studies started to explore the role of $3^{\prime}$ untranslated sequences in translational regulation. Very interestingly, fusion with 156 nucleotides of $3^{\prime}$ untranslated sequence from the mouse protamine gene delayed the translation of a human growth hormone recorder gene 38 in transgenic mice from early in spermatogenesis to the elongating spermatid stage when the protamine 1 gene is normally translated. In addition, whereas the control transgenic product was located in the acrosome, the product of the fusion gene was still intracellular, but not in the acrosome.

\section{Conclusion}

Post-meiotic gene expression is now well documented. Current studies are examining special mechanisms of transcriptional and translational regulation during spermatogenesis. Experiments designed to elucidate the mechanisms of transcript termination, polyadenylation and translational control, and signal- ing of proteins for various compartments are underway. For many genes, such as proto-oncogenes, for which the reason for post-meiotic expression remains unexplained, targeted 'knock outs' by homologous replacement in embryonic stem cells will be pursued. However, because homologous replacement of those genes that are also expressed in the early embryo may cause embryonic lethality, one may need to use antisense transgenes, which have the potential to cause a conditional mutation of the function if a testis-specific promoter is used.

\section{Acknowledgements}

I thank Dr Stan Blecher for critical conımenis, Ms Judy Worley for secretarial assistance and Dr Mary Lou Pardue for sharing recent results; financial support provided by NIH grant HD20670.

\section{References}

1 Brink, R. and Burnham, C.R. (1927) Genetics 12, 348-378

2 Frova, C., Binelli, G. and Ottaviano, E. (1987) Curr. Top. Biol. Med. Res. 15, 92-120

3 Muller, H.J. and Settles, F. (1927) Z. Induk. Abstam. Vererb. 43, 285-312

4 Lyon, M.R., Glennister, P.H. and Hawker, S.G. (1972) Nature 240, 152-153

5 Erickson, R.P. (1973) Nature New Biol. 243, 210-212

6 Braun, R.E. et al. (1989) Nature 337, 373-376

7 Gould-Somero, M. and Holland, L. (1974) Wilhem Roux Arch. 174, 133-148

8 Willison, K. and Ashworth, A. (1987) Trends Genet. 3, 351-355

9 Loir, M. (1972) Ann. Biol. Anim. Biochim. Biophys. 12, 203-219

10 Kierszenbaum, A.L. and Tres, L.L. (1975) J. Cell. Biol. 65 , 258-270

11 Geremia, R., D'Agostino, A. and Monesi, V. (1978) Exp. Cell. Res. 111, 23-30

12 Erickson, R.P., Kramer, J.M., Rittenhouse, J. and Salkeld, A. (1980) Proc. Natl Acad. Sci. USA 77, 6086-6090

13 Kleene, K.C., Distel, R.J. and Hecht, N.B. (1983) Dev. Biol. 98, 453-464

14 Dudley, K., Potter, J., Lyon, M.F. and Willison, K.R. (1984) Nucleic Acids Res. 12, 4281-4293

15 Fujimoto, H., Erickson, R.P., Quinto, M. and Rosenberg, M.P. (1984) Biosci. Rep. 4, 1037-1044

16 Thomas, K.H. et al. (1989) Biol. Reprod. 41, 729-739

17 Distel, R.J., Kleene, K.C. and Hecht, N.B. (1984) Science 224, 68-70

18 Slaughter, G.R., Meistrich, M.L. and Means, A.R. (1989) Biol. Reprod. 40, 394-405

19 Erickson, R.P. et al. (1985) Biosci. Rep. 5, 1087-1091

20 Heidaran, M.A., Showman, R.M. and Kistler, W.S. (1988) J. Cell. Biol. 106, 1427-1433

21 Moss, S.B., Challoner, P.B. and Groudine, B. (1989) Dev. Biol. 133, 83-92

22 Adham, I.M. et al. (1;99) Eur. J. Biocbem. 182, 563-568

23 Willison, K. et al. (1989, rell 57, 621-632

24 Zakeri, Z.F. and Wolgemuth, D.J. (1987) Mol. Cell. Biol. 7, 1791-1796

25 Kalikin, L.M. et al. (1989) Biochem. Biophys. Res Commun. 165, 1286-1291

26 Takahashi, M., Inaguma, Y., Hiai, H. and Hirose, F. (1988) Mol. Cell. Biol. 8, 1853-1856

27 Wolgemuth, D.J. et al. (1987) Proc. Natl Acad. Sci. USA $84,5813-5817$

28 Propst, R., Rosenberg, M.P. and Vande Woude, G.F. (1988) Trends Genet. 4, 183-187

29 Oppi, C., Shore, S.K. and Reddy, E.P. (1987) Proc. Natl Acad. Sci. USA 84, 8200-8204 